\title{
Population genetic structure in Fennoscandian landrace rye (Secale cereale L.) spanning 350 years
}

\author{
P. Larsson (1) - H. R. Oliveira (1) - M. Lundström (i) - J. Hagenblad (1) • \\ P. Lagerås $\cdot$ M. W. Leino
}

Received: 5 November 2018/Accepted: 26 March 2019/Published online: 2 April 2019

(C) The Author(s) 2019

\begin{abstract}
Rye (Secale cereale L.) was for centuries the economically most important crop in Fennoscandia (Denmark, Finland, Norway and Sweden). Historical records tell of a range of different types adapted to climate and varying cultivation practices. Genetic analyses of genebank maintained landrace rye have yet failed, with a few exceptions, to detect differentiation between rye types. Concerns have been raised that genebank material does not truly reflect the historical variation in landrace rye. In this study, we
\end{abstract}

Electronic supplementary material The online version of this article (https://doi.org/10.1007/s10722-019-00770-0) contains supplementary material, which is available to authorized users.

P. Larsson · H. R. Oliveira · M. Lundström ·

J. Hagenblad

IFM Biology, Linköping University, 58183 Linköping,

Sweden

\section{P. Larsson}

The Cultural History Association of Southern Sweden, Box 1095, 22104 Lund, Sweden

\section{P. Larsson}

Swedish Museum of Agriculture, Nordic Museum,

Box 27820, 11593 Stockholm, Sweden

\section{H. R. Oliveira}

Interdisciplinary Center for Archaeology and Evolution of Human Behaviour, Faculdade das Ciências Humanas e Sociais, Universidade do Algarve, Campus de Gambelas, 8005-139 Faro, Portugal have therefore genotyped old and historical samples of rye as well as extant material. Two historical seventeenth century samples were obtained from a grave and a museum archive respectively, and 35 old samples were taken from 100 to 140 -year-old seed collections and museum artefacts made of straw. We could confirm the results of previous studies suggesting Fennoscandian landrace rye to be one major metapopulation, genetically different from other European rye landraces, but with no support for slash-and-burn types of rye being genetically different from other rye landraces. Only small differences in genetic diversity and allele distribution was found between old landrace rye from museum collections and extant genebank

\author{
P. Lagerås \\ The Archaeologists, National Historical Museums, \\ Odlarevägen 5, 22660 Lund, Sweden \\ M. W. Leino $(\square)$ \\ The Archaeological Research Laboratory, Department of \\ Archaeology and Classical Studies, Stockholm \\ University, 10691 Stockholm, Sweden \\ e-mail: Matti.Leino@arklab.su.se
}


accessions, arguing against a substantial change in the genetic diversity during twentieth century cultivation and several regenerations during genebank maintenance. The genotypes of the old and historical samples suggest that the genetic structure of Fennoscandian landrace rye has been relatively stable for 350 years. In contrast, we find that the younger samples and early improved cultivars belong to a different genetic group, more related to landraces from Central Europe.

Keywords Ancient DNA · Genebank conservation · Kompetitive allele specific PCR (KASP) · Slash-andburn agriculture $\cdot$ Straw artefacts $\cdot$ Museum collection

\section{Introduction}

Rye (Secale cereale L.) has for centuries, along with barley (Hordeum vulgare L.), been a main crop for human consumption in Northern Europe (JuhlinDannfeldt 1926; Behre 1992; Leino 2017). Domestication of rye is believed to have happened in regions of present Turkey, Transcaucasia, Iran and Central Asia although the evolution, diversification and further spread of rye to Europe appears to have a much more complex history than wheat and barley (Behre 1992; Hagenblad et al. 2016; Parat et al. 2016; Maraci et al. 2018; Schreiber et al. 2018). In Fennoscandia (Denmark, Finland, Norway and Sweden), rye has been cultivated since the Iron Age (Viklund 2011; Grabowski 2011; Leino 2017).

Historically, rye has been cultivated on fertilized permanent fields as well as in slash-and-burn cultivation where rye was the main crop. Several historical records from the sixteenth to the early twentieth century tell that a specific type of rye ("tuvråg", "rotråg", "fälleråg") was used for slash-and-burn cultivation (Tvengsberg 1995; Ahokas 2012; Leino 2017). Other historical records instead state that the same type of rye was sown on the swidden as in the fields (Leino 2017). This conflict between records is still unsolved and may be explained by different traditions in separated regions. In addition, some historical records state that the harvest from slash-andburn cultivation was seen as excellent seed for sowing in the permanent fields (e.g. Boije 1756; Bennet 1792). As the historical records regarding rye in the slashand-burn cultivation system are ambiguous, genetic analyses of different rye accessions might shed more light on the issue.

Genetic analysis of unimproved domesticated cultivars, known as landraces, of rye preserved in genebanks has shown much more variation within the landraces than among them (Persson and von Bothmer 2002; Hagenblad et al. 2016). Compared to Fennoscandian landrace barley (Forsberg et al. 2015) rye from this region shows little differentiation between landraces from different geographic areas. It has been suggested that when a wind pollinated, outbreeding crop such as rye is grown to the extent it has been cultivated in Fennoscandia, gene flow between fields and areas has been sufficient to homogenize the genetic diversity (Hagenblad et al. 2016). Another possibility is that the genetic homogeneity observed in ex situ conserved landrace accessions is a consequence of genebank conservation practices and does not reflect historically occurring genetic structure in the field. A striking exception to the genetic homogeneity among Fennoscandian landrace rye are a few accessions of slash-and-burn rye from the Finnmarken area in Norway and Sweden, which have proved to be genetically distinct, both for nuclear and chloroplast markers (Persson and Bothmer 2000; Hagenblad et al. 2016).

The distribution of genetic diversity in landraces may be seen as historical records of former trade routes and social interactions (Jones et al. 2008; Forsberg et al. 2015). In the sixteenth and seventeenth century the government supported migration of farmers from Finland to scarcely populated forest areas in the middle of Sweden, known to this day as Finnmarken (Myrdal and Söderberg 1991). The emigrating farmers are said to have brought their own seed for sowing in large scale slash-and-burn cultivation that was used to clear land in the forest regions (Tvengsberg 1995). If this is true, the seed movement might be traceable in the genetic composition of landraces. However, such phylogeographic patterns of landraces are often obscured in studies of extant material due to intense seed trade and crop improvement in the twentieth century (Jones et al. 2008; Hagenblad et al. 2012). Use of old and historical plant materials could possibly result in clearer patterns.

Population genetics analyses of ancient DNA (aDNA) have proved very useful for studying historical biological and cultural processes, in particular studies on human migration (e.g. Fu et al. 2016; 
Skoglund et al. 2017; Lipson et al. 2017). Only a small proportion of aDNA studies have focused on plant materials (Parducci et al. 2017), even if plant specimens are commonly found at excavation sites (Jacomet et al. 1999). DNA survival over time is dependent on preservation conditions affecting the various degradation mechanisms (review in Pääbo et al. 2004). Successful DNA-analyses have been achieved on ancient desiccated cereals (e.g. Mascher et al. 2016; Hagenblad et al. 2017). In contrast, cereals preserved in a charred or waterlogged state has turned out to be notoriously difficult for DNA-studies (Fernández et al. 2013; Nistelberger et al. 2016; Lundström et al. 2018). In Fennoscandia, the climate makes desiccated materials rare in typical archaeological contexts. Instead desiccated materials have to be searched for in buildings, crypts, archives etc. where grains sometimes have been protected from decomposition or predation.

For some time studies in population genetics have, in addition to archaeological and extant materials, also used material from museum collections (Nachman 2013). The interest in using museum specimens has grown in relation to improved methods for DNA extractions and analysis. Most of these studies deal with material collected for taxonomic use, species mapping or in a broader sense for natural history collections (Wandeler et al. 2007; Bi et al. 2013; Nachman 2013). In addition, collections held by cultural history museums across the globe, contain thousands of artefacts that may hold material of interest for population genetic studies. An advantage of this type of material is its un-biased nature; most artefacts have been collected based upon other factors than genetic properties and is likely to represent the commonly available population of the material of interest.

The primary aim of this study was to investigate the population structure of historical, old and extant landrace material of rye in Fennoscandia to see whether the material types show different levels of genetic differentiation. In particular, the question of genetic differences between rye used in slash-andburn cultivation and rye cultivated on permanent fields was addressed and the hypothesis of a Finnish origin of Swedish/Norwegian slash-and-burn rye tested. We furthermore traced the genetic influence of crop improvement of cultivated rye in the early twentieth century. To address these questions, we have used a unique material consisting of rye dating to the seventeenth century, rye from nineteenth century straw decorations and grains from nineteenth and early twentieth century seed collections and compared this with extant landrace material preserved ex situ n genebanks.

\section{Materials and methods}

\section{Plant materials}

Grains from 62 accessions of rye (Sceale cereale L.) were investigated (Table 1, Fig. 1, Online resource 1). Twenty-five extant rye accessions (denoted extant below), categorised as landrace material but maintained ex situ, were supplied by NordGen (Nordic Genetic Resource Center, accession prefix NGB). Thirty-five accessions consisted of non-viable grains from museum collections (denoted old below). These were of two origins; 24 accessions from historical seed collections originating from the late nineteenth and early twentieth century (Leino et al. 2009) (Fig. 1a) while the remaining grains were found in eleven straw artefacts, such as Christmas decorations, collected in late nineteenth and early twentieth century (Fig. 1d). All artefacts are stored at the Nordic museum, a Swedish museum of cultural history. These have accession numbers with prefix NM and details are given in Online resource 1. The historical seed collections are either stored at the Nordic museum or at Tromsö museum (prefix TROM). The old accessions include two different culton types: landraces and improved cultivars. Cases where culton type was unknown, materials grown prior to 1910, when improved cultivars of rye were introduced in Scandinavia (Gunnarsson 1997), were assumed to be of landrace origin. As the old accessions have not been re-generated since their gathering, they could be considered as in situ samples.

In addition, two accessions from the seventeenth century were investigated (denoted historical). Six grains were obtained from the grave of the Danish/ Swedish bishop Peder Winstrup, Lund, who died in December 1679 (Fig. 1c). The coffin has been kept in a crypt beneath Lund Cathedral in cold and dry conditions and the bed was stuffed with different plant materials (Lagerås 2016). Two samples came from the pillow (artefact nr. DM 352:4) whereas four were 
Table 1 Summary of included Fennoscandian accessions

Extended information on each accession are given in Online resource 1

\begin{tabular}{llll}
\hline Age class & Culton type & & \\
\cline { 2 - 4 } & Landrace & Cultivar & Unknown \\
\hline Extant & 25 & & \\
Old (1869-1927) & & 8 & 8 \\
Seed collection & 16 & & \\
Museum artefact & 3 & & \\
Historical (Seventeenth century) & 2 & & \\
\hline
\end{tabular}

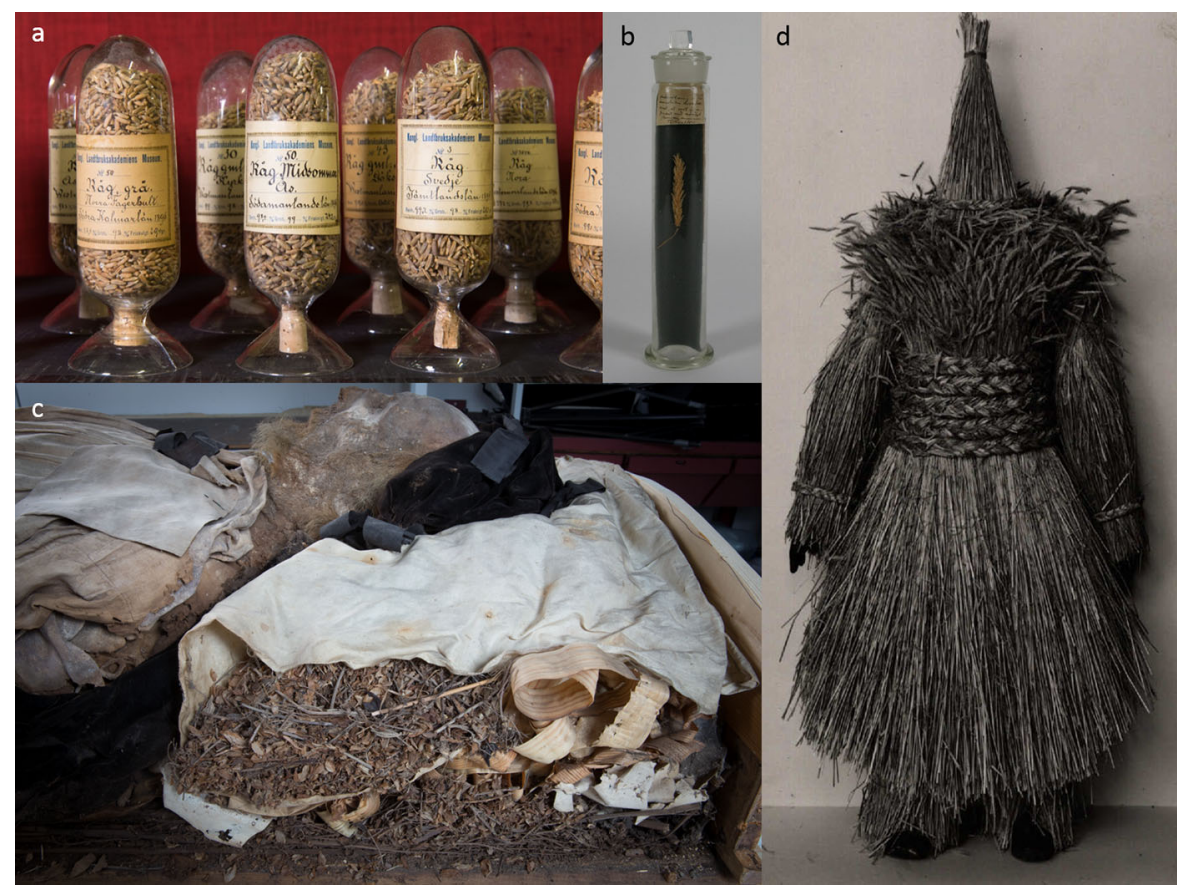

Fig. 1 Examples of old and historical materials used in the study. a Old rye samples from 1896, Nordic Museum, Sweden. b The rye spike found in a historic document created in March 1648. c The grave of bishop Peder Winstrup (1605-1679), Lund

collected from the mattress (artefact. nr. DM 352:6). The botanical samples including rye (DM 357) are stored at the Historical Museum at Lund University. The second historical accession was obtained from a rye spike (Fig. 1b) found in a document from Leppävirta, Northern Savonia, Finland delivered in May 1648 to the Royal Swedish war collegium and found in the Military Archives of Sweden in 1924. The spike was then transferred to the collection belonging to the Swedish agricultural museum and there displayed in a closed glass jar. This sample is stored at the Nordic Museum (NM.0407512).
Cathedral, Sweden, photo: Gunnar Menander. The rye grains analysed in this study were taken from the pillow and the madras stuffed with plant material. d Straw decoration from the cultural history collection at Nordic museum, Stockholm, Sweden

\section{DNA extractions and SNP genotyping}

For extant and old accessions DNA was extracted from up to six single grains per accession (Table 1) using the DNeasy Plant Mini Kit (Qiagen, Hilden, Germany). Each grain was considered as one individual. For the seventeenth century historical rye grains DNA extraction was conducted according to the Gilbert method as described in Wales et al. (2014), but with the overnight incubation at $37^{\circ} \mathrm{C}$. DNA extraction of the seventeenth century materials was carried out in an ancient-DNA facility at Oslo University, a facility that had not been used for PCR 
or work with modern rye DNA. Standard precautions for work with aDNA were taken to avoid introducing contamination (Cooper and Poinar 2000; Gilbert et al. 2005).

Extracted DNA from extant, old and historical samples were sent to LGC Genomics Ltd., UK, for KASP genotyping. A total of 40 SNPs were chosen amongst those genotyped by Hagenblad et al. (2016) based on their power to genetically differentiate among Fennoscandian rye. Historical samples, except for negative controls, were run in duplicates, but with one of the samples in each duplicate being diluted to $75 \%$ of original concentration to alleviate the effect of potential of PCR inhibitors. In addition, data from 77 Fennoscandian rye individuals from 14 accessions analysed by Hagenblad et al. (2016) were included in the analyses.

\section{Statistical analysis}

Analysis of molecular variance (AMOVA) was carried out using GenAlEx 6.5 (Peakall and Smouse 2012). GenAlEx was also used to calculate measures of within-accession genetic diversity measured as $\mathrm{He}$, the expected heterozygosity under Hardy-Weinberg equilibrium.

Pairwise $\mathrm{F}_{\mathrm{ST}}$ and Jost's $\mathrm{D}$ values were calculated to obtain the level of genetic differentiation between the populations (Jost 2008). The calculations were done in $\mathrm{R}$ v.3.5.2 (R Core Team 2019) using the packages adegenet (Jombart et al. 2018), hierfstat (Goudet and Jombart 2015) and pegas (Paradis et al. 2018). Resulting negative values were set to zero.

Principal component analysis (PCA) was performed for two sets of data. The first dataset used data from the 38 successfully analysed SNPs but excluded the data from the grains from the Winstrup grave. To analyse the rye from the Winstrup grave a second dataset was created including these, but based only on the 21 SNPs successfully genotyped in this material. Both PCAs were performed on an accession level using a matrix of allele frequencies for each accession at each locus. The PCA calculations and illustrations were made in $\mathrm{R}$ v. 3.5.2.

The software Structure (v.2.3.4) (Evanno et al. 2005) was used to cluster accessions into genetic groups. The simulations were carried out using the admixture model with 20,000 iterations for the burn-in period followed by 40,000 iterations to estimate the parameters. The simulations were repeated 10 times for each assumed level of clusters $(K=1-10)$. Calculation of $\Delta \mathrm{K}$ was done in Structure Harvester (v0.6.94) (Earl and von Holdt 2012). To evaluate and visualize the structure output, the 10 repeats for each K were merged using the CLUMPP software (v. 1.1.2) using the Greedy algorithm and random input orders (Jakobsson and Rosenberg 2007). ANOVA was used to test whether different material groups clustered significantly different in the Structure analysis. The proportion from each cluster from the CLUMPP output when processing the Structure analysis was used as a response and the type of origin (e.g. extant or historic) as factor. The individuals were blocked within their population.

\section{Results}

Genotyping success rate

In total, 338 individuals (single grains) belonging to 62 accessions were genotyped for 40 SNPs of which 38 were successfully genotyped for the majority of the individuals $(<10 \%$ missing data). Individuals with $10 \%$ or more missing data were excluded from the analysis. In total, only 17 of the analysed individuals failed to generate sufficient data to be included in the analyses (Table 1). Of these, ten were individuals from extant material and seven were individuals from old material (four from Christmas decorations, three from the seed collection). Negative controls gave no signals. All DNA extracts from the historical accessions were genotyped in duplicate and calls were in all cases identical. The two grains found in a historical document from March 1648 (NM.0407512) could both be genotyped for all 38 SNPs. The analysed grains from the Winstrup grave (DM 357) gave more than $10 \%$ missing data and for three of the grains genotyping failed completely. However, three grains produced some data and when excluding 17 failing SNPs (21 SNPs remained) the success rates were 13, 34 and $53 \%$ respectively. The data from these three grains was included in analyses on a population level with a reduced number of SNPs, but excluded when data was analysed on an individual level. 
Genetic diversity

Within-accession genetic diversity ranged from 0.155 for the accession NGB13868 to 0.370 for the accession NM.0407671 (Online resource 1). Not unexpectedly, the two seventeenth century grains coming from the same ear, from the Royal Swedish war collegium (NM.0407512) had low genetic diversity (0.190). In contrast, two of the Christmas decorations, from which also only two kernels could be successfully genotyped (NM.0106019 and NM.0222845), showed medium high levels of genetic diversity (0.276 and 0.243 respectively). These, however, may well originate from different ears. For the landrace accessions the within-accession diversity of the old accessions (mean 0.316 ) did not differ from extant landraces (mean $0.312, t$ test $p>0.05$ ). Among the old accessions the within-accession diversity of landraces (mean 0.316) did not differ from that of the improved cultivars (mean 0.310).

AMOVA showed that the majority of the genetic diversity was found within individuals (76\%), and only $6 \%$ of the variance was found among the accessions (Table 2). Less than $1 \%$ of the variation was found between age class (old and historical vs. extant). The calculated pairwise $\mathrm{F}_{\mathrm{ST}}$ and $\mathrm{D}$ values were over all low, also when comparing old and extant accessions (Online resource 2). The accession NGB13868 was however found to be strongly differentiated from the other rye populations. Some extant landraces (e.g. NGB6918, NGB14283, NGB18678 and NGB21083) as well as some of the improved cultivars (e.g. NM.0405502, NM0405512, NM.0405520) appeared to be slightly differentiated from the other extant and old landrace accessions.

Structuring of genetic diversity

In Structure analysis $\Delta \mathrm{K}$ values suggested that clustering the data into two or five groups best described structure (Online resource 3). At neither level of clustering did the accessions cluster according to age class or culton type (Fig. 2a, b). At $\mathrm{K}=2$ no clear visual differences were detected between groups (Fig. 2a). At $\mathrm{K}=5$ some of the improved cultivars, released by the breeding institute Svalöf in the early twentieth century (in particular NM.0405520, NM.0405502 and NM.0405512), predominantly clustered together in one cluster (blue in Fig. 2b) as did some of the straw decorations (NM.0165357 and NM.0165363 both from 1927). Another cluster (yellow in Fig. 2b) contained the extant landraces NGB6918 and NGB21083, but also the historical accession from the Royal Swedish war collegium (NM.0407512). The accession NGB13868, a slashand-burn rye, formed a single cluster (red in Fig. 2b) while the remaining accessions showed mixed ancestry to a varying degree. Removing NGB13868 from the structure analysis did not result in clearer clustering results among the remaining accessions (data not shown).

The two origin groups, old and extant, were tested for different structure clustering with ANOVA, both with the data from $K=2$ and $K=5$. There was a significant difference between old and extant material when assuming two clusters $(p=0.03$; data not shown), however when excluding the outlier population NGB13868 the difference was insignificant ( $p=0.12$, data not shown). When assuming five clusters, there was no difference between old and extant material except for the cluster coloured red in Fig. 2b.

Genetic structuring was also investigated with PCA. No clear clustering could be detected in the PCA based on the larger number of SNPs (Fig. 3). The four accessions being located most peripherally along PC1 are all of extant origin (Fig. 3, Table 1). The improved cultivars and some of the old material from straw decorations are found in the lower part along PC2. Including the rye from the Winstrup grave (DM
Table 2 Analysis of molecular variation (AMOVA), performed at different levels

\begin{tabular}{lrrrl}
\hline Source of variation & \multicolumn{1}{c}{$d f$} & \multicolumn{1}{l}{ SS } & MS & Variance component \\
\hline Among type (old/extant) & 1 & 29.1 & 29.1 & $<0.1(1 \%)$ \\
Among accessions & 59 & 822.5 & 13.9 & $0.5(6 \%)$ \\
Among individuals & 256 & 2265.5 & 8.9 & $1.4(18 \%)$ \\
Within individuals & 317 & 1915.5 & 6.0 & $6.0(76 \%)$ \\
Total & 633 & 5032.6 & & 8.0 \\
\hline
\end{tabular}




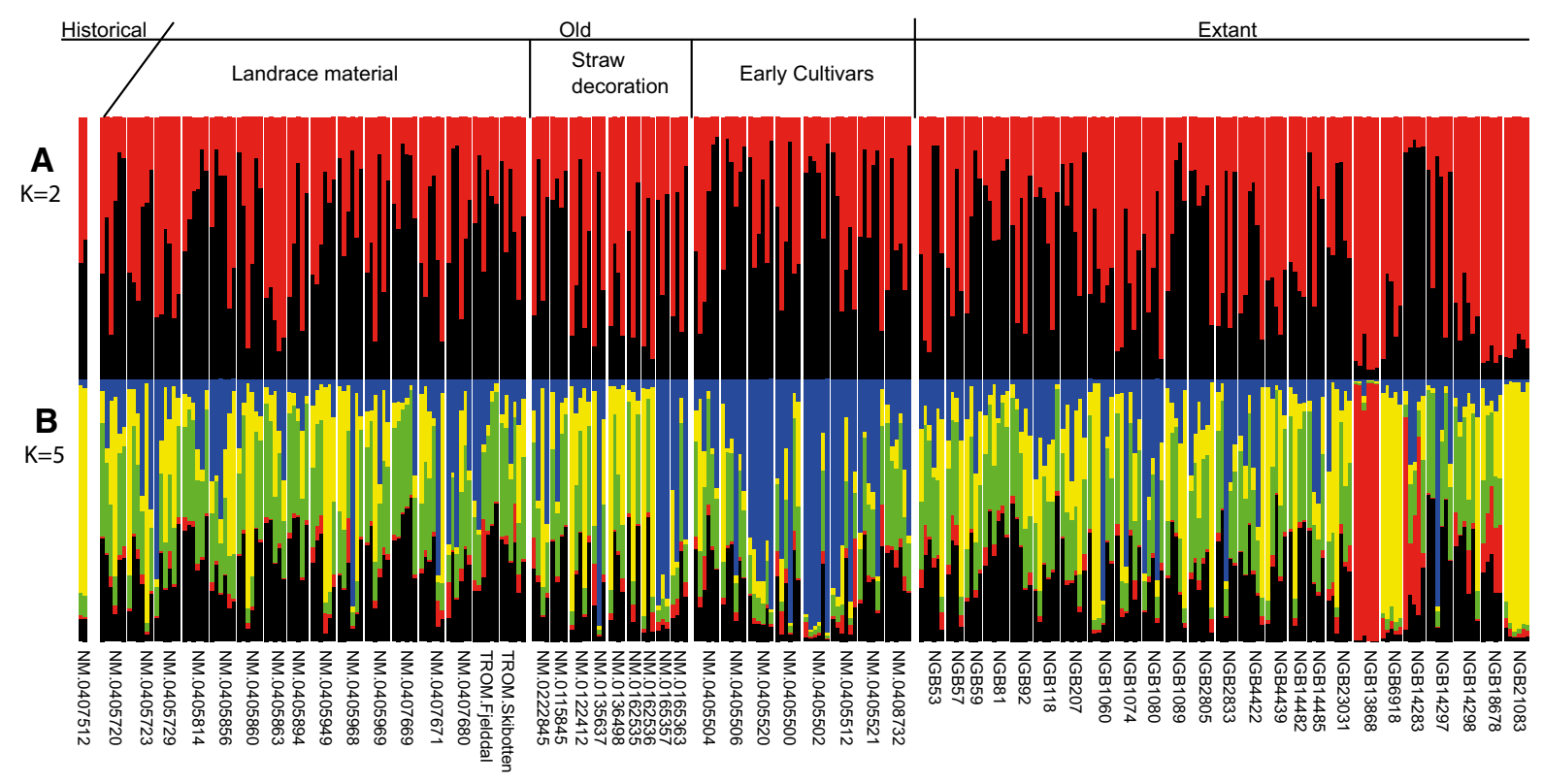

Fig. 2 Results of Structure analyses of Fennoscandian rye. Each vertical line represents data from a single individual clustered in accessions separated by small gaps. Different colours decode the proportion of identity of that individual to each cluster $(\mathrm{K})$ explained by the investigated model. The accessions are sorted by age class and culton type. $\mathbf{a} K=2$, b $\mathrm{K}=5$. (Color figure online)

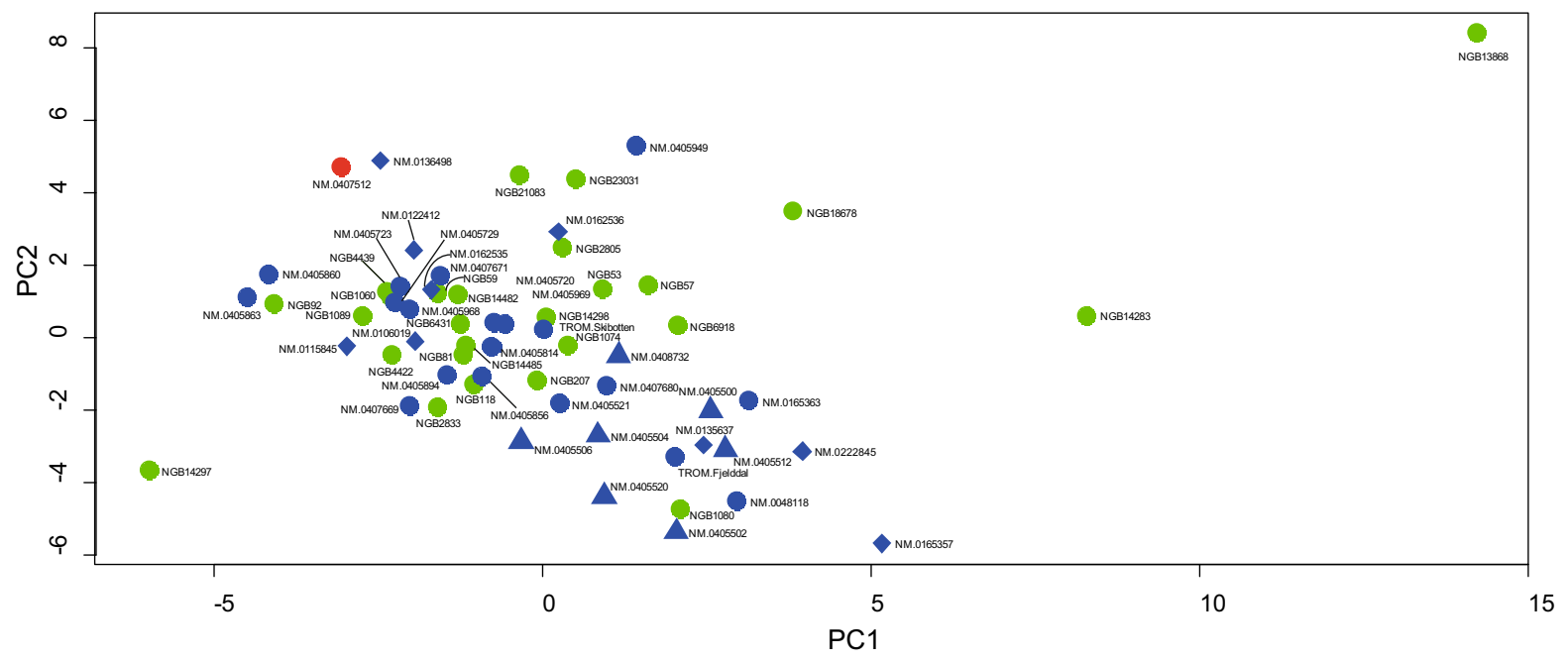

Fig. 3 PCA on accession level, based upon calls from 38 SNPs and 63 accessions. Colours represent age class: red: historical, blue: old, green: extant. Shapes represent culton type: filled

357) meant reducing the number of SNPs. In a PCA of this dataset rye from a Christmas decoration from Knäred in the county of Halland in southernmost Sweden, collected in 1885 (NM.0048118), was located most closely to the Winstrup rye (DM 357) (Fig. 4). Although the Winstrup rye (DM 357) was circle: landrace, filled diamond: old straw decorations, filled triangle: early cultivars. (Color figure online)

peripherally located it could not be considered an outlier.

We furthermore compared our data to a larger set of extant European landrace rye investigated by Hagenblad et al. (2016) (online resources 4). In Structure analysis $\Delta \mathrm{K}$ values suggested that three clusters best 


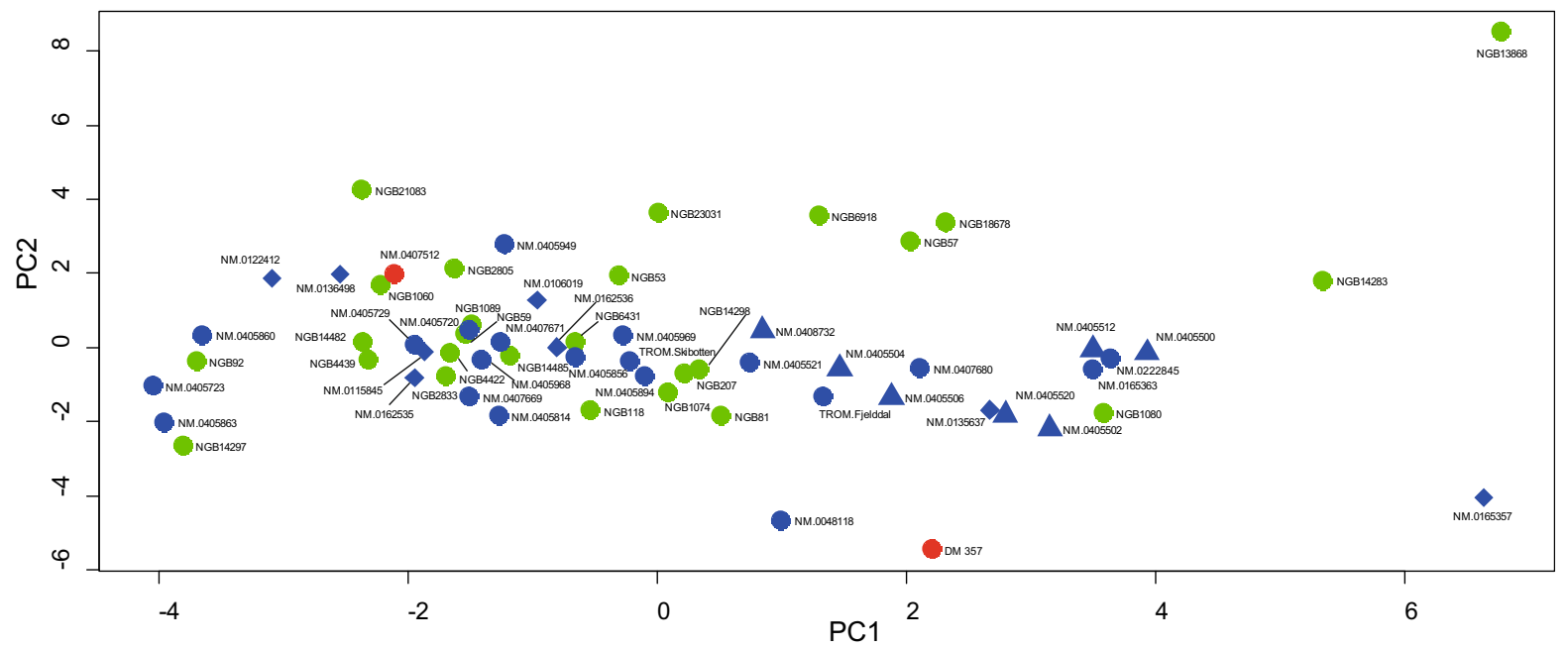

Fig. 4 PCA on accession level, based upon a dataset including 64 accessions with a reduced number (21) of called SNPs. Colours represent age class: red: historical, blue: old, green:

described the structure. The landraces (historical, old and extant accessions) from Fennoscandia belonged pre-dominantly to the same cluster (red in Fig. 5), whereas landraces from the remaining part of Europe mostly belonged to either of two other clusters (green and black in Fig. 5). Several of the improved cultivars, as well as some of the accessions of the younger straw decoration material, belonged to the same cluster as some of the European landraces (black in Fig. 5).

The proportions of the three suggested clusters from the Structure analysis were used as a response in three individual ANOVAs where the three groups extant. Shapes represent culton type: filled circle: landrace, filled diamond: old straw decorations, filled triangle: early cultivars. (Color figure online)

'European rye', 'Scandinavian early cultivars' and 'Scandinavian landraces' were used as factors. 'Scandinavian landraces' did not share proportions of any of the clusters with 'European rye' $(p<0.01)$. However, 'Scandinavian landraces' were not significantly different from 'Scandinavian early cultivars' in proportion of second (mid in Fig. 5) cluster ( $p=0.99$ ), but differed in proportion of first and third clusters $(p<0.01)$. 'Scandinavian early cultivars' and 'European rye' did not differ in proportion of third cluster ( $p=0.92$, upper part of bars in Fig. 5), but differed in first and second clusters $(p<0.02)$.

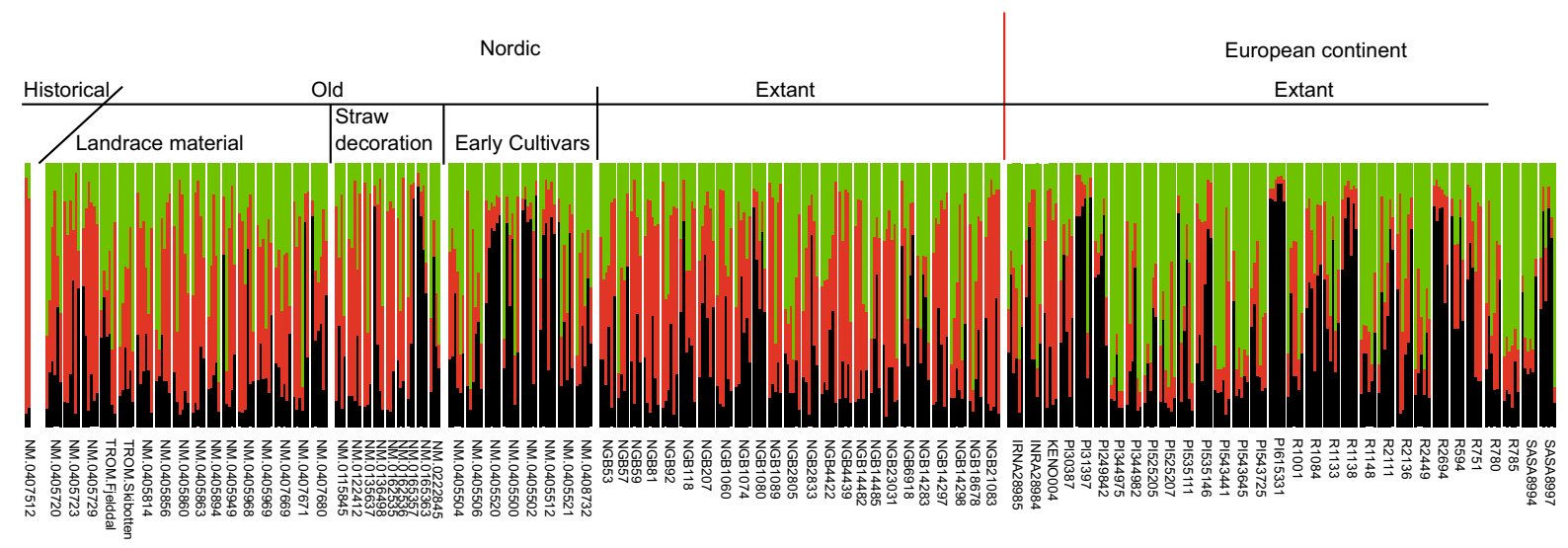

Fig. 5 Results of Structure analyses of Fennoscandian rye and European rye from Hagenblad et al. (2016) at $\mathrm{K}=3$. Each vertical line represents data from a single individual clustered in accessions separated by small gaps. Different colours decode the proportion of identity of that individual to each cluster explained by the investigated model. Accessions are sorted by geographical origin, age class and culton type. (Color figure online) 


\section{Discussion}

Genotyping of old and historical specimens

Although DNA analyses have been performed previously on nineteenth century desiccated rye grains (Leino et al. 2009; Hagenblad et al. 2012), this study prolongs the time span to 350 years. It also shows the potential in using unconventional materials, such as old Christmas decorations made out of straw with remaining grains, as source of DNA from a cultivated species such as rye. These artefacts, originally held as objects of cultural history and craft, are here shown to be useful to answer questions from a different research field. Artefacts stored at natural history museums have long proved valuable for genetic research (Bi et al. 2013; Nachman 2013) and our study should encourage searches for putative sources of DNA also in collections focused on cultural history.

In addition, the study included seventeenth century specimens which proved possible to analyse to a certain extent. In particular, the grains found in a historical document from 1648 (NM.0407512) had a high success rate. Genotyping grains from the 1679 grave of Bishop Peder Winstrup (DM 357) resulted in successful SNP calls, but the outcome was less favourable than that of the other historical sample. Likely, the storage conditions in a grave from the crypt in the cathedral of Lund were less advantageous for DNA preservation than the dry conditions in the military archive of Sweden and subsequent museum storage facilities.

It is worth noting that grains of barley (Hordum vulgare) obtained from the same grave had a higher success rate for the same type of KASP genotyping (Lundström et al. 2018). An untested hypothesis is that the hulled barley grains preserve biomolecules from degradation better than naked rye grains. In many species, properties of the seed testa are critical to protect biomolecules such as DNA from oxidative stress (Rajjou and Debeaujon 2008). However, knowledge of how different conditions affect the preservation of DNA in old and historical plant materials is scarce and interspecific differences in DNA preservation are difficult to study.

In spite of the DNA degradation in old and historical samples (Leino et al. 2009) the KASP genotyping technique produced reliable genotyping, again proving this technique suitable for genotyping of aged plant samples (Lister et al. 2013; Hagenblad et al. 2017; Lundström et al. 2018). The alternative approach with sufficient sensitivity would have been Next Generation Sequencing (NGS), a method that allows for sequencing of all DNA fragments present in a sample and suited for analysing short DNA fragments of aged samples (Brown et al. 2014; Gutaker and Burbano 2017). In addition to generation of vast quantities of data NGS gives the possibility to further verify authenticity of aged/ancient DNA by analysis of read length and DNA damage patterns. However, in order to produce comparable datasets from the different individuals massive amounts of sequence data must be generated. In case sample number is high (such as in this investigation) this would come at an unreasonably high cost. Furthermore, the analysis of NGS data would be difficult as no genome sequence of rye is yet available, although expected within the near future (Bauer et al. 2017). The choice of marker method will thus has to depend on research question, sample size and financial basis.

\section{Genetic stability of Fennoscandian landrace rye}

The old accessions of rye landraces have never been subjected to ex situ conservation, but nevertheless showed no higher levels of within-accession genetic diversity than the extant accessions gathered a century later and preserved in genebanks. The two materials also clustered among each other and pairwise $\mathrm{F}_{\mathrm{ST}}$ and Jost's D values were overall low, arguing against a substantial change in the genetic diversity during twentieth century cultivation and several regenerations during genebank maintenance. Similar observations were made by Hagenblad et al. (2012). Neither was any clustering detected among the old accessions. Thus, the historical sources telling of several distinct rye types do not find correspondence in genetic groups and neither does this absence of structuring seem to be the result of altered maintenance during the twentieth century. Had strong geographic structuring been present historically we would have expected to detect at least elements of this even with our limited dataset.

Although the limited number of markers might prevent us from detecting structuring of landraces, we note that we find no more or less genetic structure in Fennoscandian landrace rye in our SNP set compared to the more tenfold marker amount used by Hagenblad et al. (2016). It is yet possible that genetic structure 
remains hidden in the material. To reveal such putative patterns much more marker power would be required, likely on the scale of thousands of SNPs. Recently Schreiber et al. (2018) reported on genotyping-bysequencing, yielding $>55.000$ SNPs, of rye accessions. However, also with this scale of marker power, it was difficult to identify clear sub-structures within European cultivated rye accession included in their study. In contrast, certain geographical areas, such as Iberia, seem to host rye landraces clearly genetically differentiated from each other (Hagenblad et al. 2016; Monteiro et al. 2016).

The majority of accessions appear to belong to the same meta-population of Fennoscandian landrace rye observed earlier by Persson and von Bothmer (2000, 2002) and Hagenblad et al. (2012, 2016). This meta-population differs from landrace rye from other parts of Europe (Fig. 5). Exceptions within Fennoscandia (Fig. 2b, online resource 2) are the accessions NGB13868 (see below), NGB6918 and NGB21083. NGB6918 is a landrace ('Östgöta gråråg') from central Sweden that was commercialized and used in official trials until the 1950s (Leino 2017). It is not unlikely that NGB21083 (from the island of Gotland) originates from the former.

Looking at the historical accessions of rye grown in the seventeenth century neither appear to differ genetically from landrace material cultivated during the late nineteenth century. When plotting genetic similarity in a graphical PCA, the two accessions from seventeenth century show no clear distinction from landrace material collected at the end of the nineteenth century or stored as extant material in gene banks. In fact, the closest positioned accessions in the PCA are also geographically very close (DM 357NM.0048118; NM.0407512-NM.0405729; Fig. 4). The lowest value of Jost's D for pairwise comparisons with the historical accession NM.0407512 was the extant accession NGB1089, also geographically very close. In conclusion, the results tentatively suggest limited genetic turnover of Fennoscandian landrace rye between the seventeenth century, the late nineteenth century and the extant genebank accessions mostly gathered in the late twentieth century. Similar genetic stability of locally adapted field grown crops over long timespans was recently reported in barley in southern Sweden (Lundström et al. 2018) and barley in the Canary Islands (Hagenblad et al. 2017).
On the differentiation of slash-and-burn-rye

A long-standing question is whether rye historically used in slash-and-burn agriculture is genetically different from the rye cultivated on permanent fields. In the studies of Persson and Bothmer (2000, 2002) and Hagenblad et al. (2016) extant genebank accessions denoted "svedjeråg" (slash-and-burn rye) were included but could not be separated from rye grown on permanent fields. An explanation to this could be that genetic signatures might have been obscured during genebank conservation (see e.g. Hagenblad et al. 2012). In this study we do, however, see no difference in genetic diversity content or distribution between old and extant accessions. The old accession of slash-andburn rye NM.0405860 is not notably different from other landraces and neither are four accessions (NGB14298, NM.0405949, NM.0405969, NM.0405521) of "Midsommarråg" (midsummer rye); a type of rye said to be identical to slash-andburn rye (Leino 2017). In conclusion, we cannot, from the accessions and markers used in this study, find any evidence of slash-and burn rye and rye from permanent fields being genetically separate populations.

An exception in this and previous studies (Persson and Bothmer 2000; Persson and von Bothmer 2002; Hagenblad et al. 2016) is NGB13868 and related accessions. The differentiation of NGB13868 was clear also in our dataset (Figs. 2b, 3, online resource 2). This accession originates from a few rye grains found in the 1970s in an old barn in Grue Finmark, Norway (Tvengsberg 1995). The barn was located far from the main settlement in a region with a history of intensive slash-and-burn cultivation. In addition to a unique genetic signature NGB13868 showed unusually low genetic diversity. Upon investigation we found that of the original grains discovered in the barn in Grue Finmark, ten grains were sown and seven germinated. These were grown at Graminor breeding station and the accession NGB13868 originates from one of these harvests (Magne Gullord, pers.com). In a historical context it was assumed that the ancestor to this accession may have been brought to the region with immigrating farmers from Finland. In this study we failed to find any Finnish accession related to NGB13868. The low diversity and absence of a strong relationship to Finnish landraces suggest that the distinct genetic signature of NGB13868 is most likely not indicative of a unique Finnish origin, but rather a 
result of massive genetic drift during the population bottleneck. Two accessions, NGB14283 and NGB18678 clustered partly together with NGB13868 and were also somewhat differentiated from other landrace accession in pairwise $F_{S T}$ and Jost's D comparisons. In the first case, we know of a direct exchange of seed with NGB13868. The second accession was gathered in Småland, southern Sweden in 1970, and its putative relationship to NGB13868 is more elusive.

The early history of Fennoscandian rye improvement

In contrast to the genetic stability of landraces we could see patterns of genetic alteration from the early history of plant breeding of rye. The old material included both landraces (collected before the introduction of the first rye cultivars in Fennoscandia) and some of the early improved cultivars developed by the Swedish breeding institute Svalöf. In the Structure analysis neither cultivars, nor landraces formed genetically homogeneous groups but rather showed mixed ancestry. One cluster (blue in Fig. 2b), however, is particularly common among the improved cultivars, and much less common among old and extant landraces. It therefore seems likely that some of the genetic material used for rye improvement was obtained from outside of Fennoscandia. When comparing with European landraces (Fig. 5) some of the improved cultivars belong predominantly to the same genetic cluster as landraces from central Europe (Germany, Hungary, Romania, Northern Italy). This finding is explained by pedigrees of the first rye breeding in Sweden in the twentieth century that often include German cultivars, in particular 'Petkuser' (Gunnarsson 1997).

Interestingly some of the straw decorations also predominantly belong to the same cluster. Both were obtained in 1927, after the advent of rye cultivars in Fennoscandia, and both were obtained from the county of Södermanland. The remaining nine accessions obtained from straw decorations cluster similarly to the landrace material. Again, a larger number of genetic markers will provide more power to study early rye breeding. At present we tentatively observe that although historical traditions such as making straw figurines for the Christmas season still remained, some farmers had already adapted to "modern times" in terms of growing new and improved rye cultivars rather than "old-fashioned" landrace rye.

Acknowledgements The authors are grateful to the Nordic Museum and Troms $\emptyset$ Museum for granting access to sample their collections and NordGen for providing extant accessions. Dr. Sanne Boessenkool and Agata Teresa Gondek are acknowledged for access to and assistance in the aDNA facilities at Oslo University. The study was made possible by generous funding by the Lagersberg foundation, the Royal Academy of Science and the Helge Ax:son Johnson Foundation. The Crafoord Foundation financed the sampling and botanical analysis of the Winstrup grave. HRO was supported with a postdoctoral stipend from the Sven and Lilly Lawski Foundation, ML was funded by the Berit Wallenberg Foundation and MWL was funded by the Swedish Research Council.

\section{Compliance with ethical standards}

Conflict of interest The authors declare that they have no conflict of interest.

Open Access This article is distributed under the terms of the Creative Commons Attribution 4.0 International License (http:// creativecommons.org/licenses/by/4.0/), which permits unrestricted use, distribution, and reproduction in any medium, provided you give appropriate credit to the original author(s) and the source, provide a link to the Creative Commons license, and indicate if changes were made.

\section{References}

Ahokas H (2012) Crop evolution under fire: the past cultivation with sequential kytö burning selected against the shattering weedy forms and comparison between Finnish kytö and Ethiopian guie. Kave, Helsinki

Bauer E, Schmutzer T, Barilar I et al (2017) Towards a wholegenome sequence for rye (Secale cereale L.). Plant $\mathrm{J}$ 89:853-869. https://doi.org/10.1111/tpj.13436

Behre K-E (1992) The history of rye cultivation in Europe. Veg Hist Archaeobotany 1:141-156. https://doi.org/10.1007/ BF00191554

Bennet S (1792) Kort underrättelse om det Sawolaxska Swedjebruket på torra marker. Hushållningsjournal 1-2:35-49

Bi K, Linderoth T, Vanderpool D et al (2013) Unlocking the vault: next-generation museum population genomics. Mol Ecol 22:6018-6032. https://doi.org/10.1111/mec.12516

Boije CG (1756) Säkra rön och påliteliga medel til wälmågo och förmögenhet. Printed by Lor. Ludv. Grefing, Stockholm

Brown TA, Cappellini E, Kistler L et al (2014) Recent advances in ancient DNA research and their implications for archaeobotany. Veg Hist Archaeobotany 24:207-214. https://doi.org/10.1007/s00334-014-0489-4

Cooper A, Poinar HN (2000) Ancient DNA: do it right or not at all. Science 289:1139. https://doi.org/10.1126/science.289. $5482.1139 b$ 
Earl DA, von Holdt BM (2012) STRUCTURE HARVESTER: a website and program for visualizing STRUCTURE output and implementing the Evanno method. Conserv Genet Resour 4:359-361. https://doi.org/10.1007/s12686-0119548-7

Evanno G, Regnaut S, Goudet J (2005) Detecting the number of clusters of individuals using the software STRUCTURE: a simulation study. Mol Ecol 14:2611-2620

Fernández E, Thaw S, Brown TA et al (2013) DNA analysis in charred grains of naked wheat from several archaeological sites in Spain. J Archaeol Sci 40:659-670. https://doi.org/ 10.1016/j.jas.2012.07.014

Forsberg NEG, Russell J, Macaulay M et al (2015) Farmers without borders-genetic structuring in century old barley (Hordeum vulgare). Heredity 114:195-206. https://doi. org/10.1038/hdy.2014.83

Fu Q, Posth C, Hajdinjak M et al (2016) The genetic history of ice age Europe. Nature. https://doi.org/10.1038/ nature 17993

Gilbert MTP, Bandelt H-J, Hofreiter M et al (2005) Assessing ancient DNA studies. Trends Ecol Evol 20:541-544. https://doi.org/10.1016/j.tree.2005.07.005

Goudet J, Jombart T (2015) Estimation and tests of hierarchical F-statistics. R package version 0.04-22

Grabowski R (2011) Changes in cereal cultivation during the Iron Age in southern Sweden: a compilation and interpretation of the archaeobotanical material. Veg Hist Archaeobotany 20:479-494. https://doi.org/10.1007/ s00334-011-0283-5

Gunnarsson E (1997) Svensk växtförädling av höstråg. In: Olsson G (ed) Den Svenska växtförädlingens historia. KSLA, Shrevepor, pp 177-182

Gutaker RM, Burbano HA (2017) Reinforcing plant evolutionary genomics using ancient DNA. Curr Opin Plant Biol 36:38-45. https://doi.org/10.1016/j.pbi.2017.01.002

Hagenblad J, Zie J, Leino MW (2012) Exploring the population genetics of genebank and historical landrace varieties. Genet Resour Crop Evol 59:1185-1199. https://doi.org/10. 1007/S10722-011-9754-X

Hagenblad J, Oliveira HR, Forsberg NEG et al (2016) Geographical distribution of genetic diversity in Secale landrace and wild accessions. BMC Plant Biol 16:23. https:// doi.org/10.1186/s12870-016-0710-y

Hagenblad J, Morales J, Leino MW et al (2017) Farmer fidelity in the Canary Islands revealed by ancient DNA from prehistoric seeds. J Archaeol Sci 78:78-87. https://doi.org/10. 1016/j.jas.2016.12.001

Jacomet S, Kreuz A, Rösch M (1999) Archäobotanik: Aufgaben, Methoden und Ergebnisse vegetations- und agrargeschichtlicher Forschung. Ulmer, Stuttgart

Jakobsson M, Rosenberg NA (2007) CLUMPP: a cluster matching and permutation program for dealing with label switching and multimodality in analysis of population structure. Bioinformatics 23:1801-1806. https://doi.org/ 10.1093/bioinformatics/btm233

Jombart T, Kamvar ZN, Collins C et al (2018) Exploratory analysis of genetic and genomic data. $\mathrm{R}$ package version 2.1.1

Jones H, Lister DL, Bower MA et al (2008) Approaches and constraints of using existing landrace and extant plant material to understand agricultural spread in prehistory.
Plant Genet Resour 6:98-112. https://doi.org/10.1017/ S1479262108993138

Jost $L$ (2008) $G_{s t}$ and its relatives do not measure differentiation. Mol Ecol 17:4015-4026. https://doi.org/10.1111/j.1365294X.2008.03887.x

Juhlin-Dannfeldt H (1926) Lantbruket i Norden under senaste halvsekel: 1875-1925. Göteborgs Litografiska Aktiebolag, Göteborg

Lagerås $\mathrm{P}$ (2016) A fragrant grave: revealing the mummified remains of a 17th-century bishop. Curr World Archaeol 76

Leino MW (2017) Spannmål: svenska lantsorter. Nordiska museets förlag, Stockholm

Leino MW, Hagenblad J, Edqvist J et al (2009) DNA preservation and utility of a historic seed collection. Seed Sci Res 19:125-135. https://doi.org/10.1017/S0960258509990055

Lipson M, Szécsényi-Nagy A, Mallick S et al (2017) Parallel palaeogenomic transects reveal complex genetic history of early European farmers. Nature 551:368-372. https://doi. org/10.1038/nature24476

Lister DL, Jones H, Jones MK et al (2013) Analysis of DNA polymorphism in ancient barley herbarium material: validation of the KASP SNP genotyping platform. Taxon 62:779-789. https://doi.org/10.12705/624.9

Lundström M, Forsberg NEG, Heimdahl J et al (2018) Genetic analyses of Scandinavian desiccated, charred and waterlogged remains of barley (Hordeum vulgare L.). J Archaeol Sci Rep 22:11-20. https://doi.org/10.1016/j.jasrep.2018. 09.006

Maraci Ö, Özkan H, Bilgin R (2018) Phylogeny and genetic structure in the genus Secale. PLoS ONE 13:e0200825. https://doi.org/10.1371/journal.pone.0200825

Mascher M, Schuenemann VJ, Davidovich U et al (2016) Genomic analysis of 6,000-year-old cultivated grain illuminates the domestication history of barley. Nat Genet 48:1089-1093. https://doi.org/10.1038/ng.3611

Monteiro F, Vidigal P, Barros AB et al (2016) Genetic distinctiveness of rye in situ accessions from Portugal unveils a new hotspot of unexplored genetic resources. Front Plant Sci 7:1334. https://doi.org/10.3389/fpls.2016.01334

Myrdal J, Söderberg J (1991) Kontinuitetens dynamik: agrar ekonomi i 1500-talets Sverige. Almqvist \& Wiksell International, Stockholm

Nachman MW (2013) Genomics and museum specimens. Mol Ecol 22:5966-5968. https://doi.org/10.1111/mec.12563

Nistelberger HM, Smith O, Wales N et al (2016) The efficacy of high-throughput sequencing and target enrichment on charred archaeobotanical remains. Sci Rep 6:37347. https://doi.org/10.1038/srep37347

Pääbo S, Poinar H, Serre D et al (2004) Genetic analyses from ancient DNA. Annu Rev Genet 38:645-679. https://doi. org/10.1146/annurev.genet.37.110801.143214

Paradis E, Jombart T, Brian K et al (2018) Population and evolutionary genetics analysis system. $\mathrm{R}$ package version 0.11

Parat F, Schwertfirm G, Rudolph U et al (2016) Geography and end use drive the diversification of worldwide winter rye populations. Mol Ecol 25:500-514. https://doi.org/10. 1111/mec.13495

Parducci L, Bennett KD, Ficetola GF et al (2017) Ancient plant DNA in lake sediments. New Phytol 214:924-942. https:// doi.org/10.1111/nph.14470 
Peakall R, Smouse PE (2012) GenAlEx 6.5: genetic analysis in Excel. Population genetic software for teaching and research-an update. Bioinformatics 28:2537-2539. https://doi.org/10.1093/bioinformatics/bts460

Persson K, Bothmer RV (2000) Assessing the allozyme variation in cultivars and Swedish Landraces of Rye (Secale Ceveale L.). Hereditas 132:7-17. https://doi.org/10.1111/j. 1601-5223.2000.00007.x

Persson K, von Bothmer R (2002) Genetic diversity amongst landraces of rye (Secale cereale L.) from northern Europe. Hereditas 136:29-38

R Core Team (2019) A language and environment for statistical computing. R Foundation for Statistical Computing, Vienna, Austria. http://www.R-project.org/

Rajjou L, Debeaujon I (2008) Seed longevity: survival and maintenance of high germination ability of dry seeds. C R Biol 331:796-805. https://doi.org/10.1016/j.crvi.2008.07. 021

Schreiber M, Himmelbach A, Börner A et al (2018) Genetic diversity and relationship between domesticated rye and its wild relatives as revealed through genotyping-by-sequencing. Evol Appl 2018:1-12. https://doi.org/10.1111/ eva.12624
Skoglund P, Thompson JC, Prendergast ME et al (2017) Reconstructing prehistoric African population structure. Cell 171:59-71.e21. https://doi.org/10.1016/j.cell.2017. 08.049

Tvengsberg PM (1995) Det värmlandsfinske svedjebruket. In: Larsson B (ed) Svedjebruk och röjningsbränning i Norden: terminologi, datering, metoder. Nordiska museet, Stockholm, pp 109-118

Viklund K (2011) Early farming at Umeå in Västerbotten: charred cereal grains dated to the Bronze Age. Fornvännen 106:238-242

Wales N, Andersen K, Cappellini E et al (2014) Optimization of DNA recovery and amplification from non-carbonized archaeobotanical remains. PLoS ONE 9:e86827. https:// doi.org/10.1371/journal.pone.0086827

Wandeler P, Hoeck PEA, Keller LF (2007) Back to the future: museum specimens in population genetics. Trends Ecol Evol 22:634-642. https://doi.org/10.1016/j.tree.2007.08. 017

Publisher's Note Springer Nature remains neutral with regard to jurisdictional claims in published maps and institutional affiliations. 